International Research Journal of Management, IT \& Social Sciences
Available online at https://sloap.org/journals/index.php/irjmis/
Vol. 6 No. 6, November 2019, pages: 220 228
ISSN: 2395-7492
https://doi.org/10.21744/irjmis.v6n6.797

\title{
Performance of Stock Portfolio Based on Contrarian Strategy in Indonesia Stock Exchange
}

\author{
I Gede Wira Pratama ${ }^{a}$ \\ Henny Rahyuda ${ }^{\mathrm{b}}$
}

\section{Article history:}

Received: 09 July 2019

Accepted: 30 September 2019

Published: 11 November 2019

Keywords:

abnormal return; contrarian strategy;

kompas 100 index;

overreaction;

portfolio;

\begin{abstract}
This study aims to determine the differences in the performance of high abnormal stock portfolio during the test period compared with the performance of the stock portfolio in the formation period, the difference in the performance of the low abnormal return of the test period compared to the portfolio performance of the stock formation period, as well as the difference in the performance of the high abnormal return stock portfolio (winner) compared with a low abnormal return (loser) test period. The sample consists of shares included in the Kompas 100 index which are listed on the Indonesia Stock Exchange. The sampling method used in this study is a tiered sampling method that is analyzed by means of the two different test. The results showed that within a period of 12 months, there was a positive difference of $10.59 \%$ in the loser stock portfolio against the winner stock portfolio in the next period. Stocks that initially had low abnormal returns (losers) experienced a greater return reversal than the winner stock portfolio return in the next period, indicating a market anomaly associated with the overreaction hypothesis. Based on these results, contrarian strategies can be used by investors and investment managers to form a portfolio within a period of 12 months.
\end{abstract}

2395-7492@ Copyright 2019. The Author. This is an open-access article under the CC BY-SA license (https://creativecommons.org/licenses/by-sa/4.0/) All rights reserved.

\section{Author correspondence: \\ I Gede Wira Pratama, \\ Faculty of Economics, Udayana University, Denpasar, Indonesia. \\ Email address: gedewira1993@gmail.com}

\section{Introduction}

To be able to obtain optimal results from stock investments, investors can make an investment analysis before investing in the funds. Stock investment analysis is a fundamental thing that must be known by investors. Markowitz (1952), who first described investment analysis by combining various assets in an efficient portfolio. Investors often diversify their investments by combining various securities. There is a lot of debate about investment strategies that investors can use to form stock portfolios.

a Udayana University, Denpasar, Indonesia

${ }^{\mathrm{b}}$ Udayana University, Denpasar, Indonesia 
In certain conditions often the phenomenon of excessive reaction (overreaction) due to investor psychological factors in responding to an event related to the stock. An overreaction is a form of market inefficiency in the presence of asymmetric information, a condition that shows when some investors have information that is not owned by others. The inefficiency of the market was first shown by De Bondt \& Thaler (1985), that markets tend to overreact in responding to good (bad news) or bad (bad news) information. This overreaction hypothesis is the cause of the winnerloser anomaly, ie stocks that initially (formation grade) obtain a positive (winner) or negative (loser) return rate will experience a reversal in the subsequent period (subsequent test period). Regarding the winner-loser anomaly, the return reversal experienced by the loser and winner stocks has led to an investment strategy namely contrarian investment strategies (Widiastuti \& Jaryono, 2011).

Contrarian strategy is a strategy in investing in stocks carried out by buying shares that have performed poorly in the past which are considered loser shares and selling stocks that performed well in the past, which are considered as winning shares. Contrarian investment strategies were first discovered by De Bondt \& Thaler (1985). Using US capital market data, they found that stocks that initially gave a positive return (winner stock) or stocks that had a negative rate of return (loser stock) would experience a reversal in subsequent periods.

Informing a portfolio based on a contrarian strategy there are stocks with high and low abnormal returns that are grouped in the formation period. The formation period is the period of formation of shares to determine the shares to be sold and bought. The results of these stock transactions will be known in the ownership period. The ownership period is the testing period after the formation period to find out which stock prices move up or down. The period of formation and ownership uses a period of 3, 6, and 12 months. This time period represents stock price movements in the short term (1-6 months) and long term (6 months and above).

Empirical research on stock selection into portfolios using technical analysis with abnormal returns has been done by Deger \& Ebru (2017), on the Istanbul Stock Exchange with the results leading to reversal returns. Analysis conducted shows that the contrarian investment strategy is a profitable investment strategy on the Istanbul Stock Exchange in all periods. Investors in the Indonesian capital market should use a contrarian investment strategy which is the opposite of the momentum investment strategy to form a stock portfolio, because the findings of this study indicate that stocks that initially provided a positive return (winner) and a negative return (loser) experienced a reversal (reversal) at the end of the testing period or ownership period. Bodie \& Marcus (2010), state that the increase in abnormal returns obtained from this contrarian investment strategy is largely generated by the existence of a reversal effect caused by investors overreacting.

Pedro et al., (2017), who conducted research on the United States stock exchange during 1926-2013. They found that overreaction was driven by the performance of loser shares in the formation period returning to strengthen in the next period even having a smaller beta level compared to winner shares. This can show that the contrarian strategy applies in the United States stock exchanges. Farag (2015), which states that contrarian strategies have beneficial results in the Egyptian capital market. Stocks in the formation period have a negative abnormal return which results in performance that is different from the performance in the following period because market participants consistently overreact to the future growth rate for share growth compared to stock value.

Based on several studies of foreign capital markets, this study was conducted to find out whether there was also an overreaction phenomenon in the Indonesian capital market. This phenomenon causes differences in performance between the stock portfolio formation period against the stock portfolio testing period. The difference is in the form of changes in stock performance from which originally had a high abnormal return in the formation period and then turned into a low abnormal return in the next period. Reversal is caused by investors initially overreacting to good information (overreaction) by buying shares of high abnormal returns.

To find out which contrarian strategies can be applied in the Indonesian capital market, research is conducted on whether there is a difference in performance between a high abnormal return portfolio and a low abnormal return in the testing period. The impact of excessive reactions that occur, in theory, a low abnormal return produces greater performance than a high abnormal return in the test period so that the contrarian strategy can be the right strategy to use.

The purpose of this study was to determine the difference in performance between a portfolio of stock formation period with the stock portfolio testing period based on high abnormal returns, to determine the difference in performance between the stock portfolio formation period with the stock portfolio testing period based on low abnormal returns, and to know the difference in performance between abnormal stock portfolios low return with a high abnormal return stock portfolio in the test period.

Pratama, I. G. W., \& Rahyuda, H. (2019). Performance of stock portfolio based on contrarian strategy in indonesia stock exchange. International Research Journal of Management, IT and Social Sciences, 6(6), 220-228. 


\section{Materials and Methods}

\section{Data collection technique}

Data collection can be done by non-participant observation. Non-participant observation is a method and technique of data collection where the observer is separately located as an observer. In this study, researchers were not directly involved in the object being observed. Observations are made by opening and downloading from the site www.yahoo.finance.com so that the issuer's stock returns and market returns can be obtained

\section{Data source}

The data used in this study are secondary data obtained indirectly by researchers, obtained from data owned by companies, literature studies, literature, previous research journals and articles relating to the problem being investigated. The data consists of the Composite Stock Price Index (CSPI) and the share price of listed companies listed on the Kompas 100 index on the Indonesia Stock Exchange. The form of data is time-series data with a monthly frequency from January 2008 to December 2018. The data used in this study were obtained from the website www.yahoo.finance.com

\section{Sample}

The sample is the part or number and characteristics possessed by the population. The research sample selection method is carried out using a multi-phase sampling procedure with the following stages:

1) Population stocks are grouped into sample units based on the level of return (high returns for stocks that have returns above the average return and low returns for stocks that have returns below the average return).

2) Selecting stocks that are sampled to be included in the winner's stock portfolio (the stock portfolios that represent the 20 that have the highest return), and the loser stock portfolio (the stock portfolio that represents 20 shares that have a low return). Each portfolio is equally weighted, valid for the next 3,6 and 12 months as a testing period, and investments are made arbitrarily (zero cost investment). Forming a portfolio with equally weighted results in an optimal portfolio that is better than a simple diversification method.

Determination of the number of shares based on the sampling stage then determined 20 shares included in the portfolio with recommendations of several empirical findings about the minimum number of shares in the portfolio such as Hirt \& Block (1989), recommending the number of shares included in the portfolio is from 10 to 20 shares, French (1989); Sharpe \& Alexander (1990), Moskowitz \& Grinblatt (1999); Pramanaswari \& Yasa (2018), recommend that a minimum of 10 shares be included in a portfolio, and the benefits of better diversification can be achieved by including shares from various industries in the portfolio (Wiagustini, 2008; Wartawan, 2017).

\section{Data analysis technique}

The significance of the difference in portfolio performance between high abnormal return shares and low abnormal returns in the formation period with high abnormal return shares and low abnormal returns in the ownership period is performed using the statistic difference test or t-test. According to Sitangshu (2014), to describe the level of difference between the two abnormal returns the t-test statistical test was used. The test is carried out to compare whether the two mean abnormal returns in the period of formation and ownership are the same or different. Different test calculations will be explained as follows:

$$
\mathrm{t}=\frac{\overline{\mathrm{X}}_{1}-\overline{\mathrm{X}}_{2}}{\sqrt{\frac{\left(\mathrm{n}_{1}-1\right) \mathrm{S}_{1}{ }^{2}+\left(\mathrm{n}_{2}-1\right) \mathrm{S}_{2}{ }^{2}\left(\frac{1}{\mathrm{n}_{1}}+\frac{1}{\mathrm{n}_{2}}\right)}{\mathrm{n}_{1}+\mathrm{n}_{2}-2}}}
$$

Information:

$\mathrm{X}_{1}=$ average abnormal stock return of the test period

$\mathrm{X}_{2}=$ Average abnormal stock returns of the formation period 
$\mathrm{S}_{1}=$ Standard deviation of the portfolio of the test period

$\mathrm{S}_{2}=$ Standard deviation of the stock portfolio in the formation period

$\mathrm{n}=$ Number of observations

\section{Results and Discussions}

\subsection{Winner-Loser Stock Portfolio Performance}

The results of the calculation of the cumulative average abnormal return of the winner-loser stock portfolio formation period of 3.6, and 12 months and the testing period of 3.6, and 12 months thereafter can be seen in the following table.

Table 1

Average Cumulative Abnormal Return of Loser Stock Portfolio and Winner of Compass 100 Index Formation Period and 3-Month Testing Period 2008 - 2018

\begin{tabular}{|c|c|c|c|c|}
\hline & \multicolumn{2}{|c|}{ Loser } & \multicolumn{2}{|c|}{ Winner } \\
\hline & Formation & Testing & Formation & Testing \\
\hline Observation 1 & $-5.11 \%$ & $5.97 \%$ & $35.21 \%$ & $25.81 \%$ \\
\hline Observation 2 & $-4.74 \%$ & $-10.31 \%$ & $29.26 \%$ & $-13.33 \%$ \\
\hline Observation 3 & $-10.28 \%$ & $8.09 \%$ & $135.45 \%$ & $18.72 \%$ \\
\hline Observation 4 & $-3.87 \%$ & $5.00 \%$ & $28.59 \%$ & $-0.63 \%$ \\
\hline Observation 5 & $-7.43 \%$ & $-2.46 \%$ & $50.45 \%$ & $-8.77 \%$ \\
\hline Observation 6 & $-3.80 \%$ & $5.62 \%$ & $51.96 \%$ & $1.54 \%$ \\
\hline Observation 7 & $-5.77 \%$ & $16.87 \%$ & $22.90 \%$ & $18.87 \%$ \\
\hline Observation 8 & $-4.62 \%$ & $2.67 \%$ & $17.20 \%$ & $4.25 \%$ \\
\hline Observation 9 & $-3.03 \%$ & $-4.71 \%$ & $35.68 \%$ & $-3.15 \%$ \\
\hline Observation 10 & $-4.34 \%$ & $3.40 \%$ & $17.00 \%$ & $5.46 \%$ \\
\hline Observation 11 & $-8.93 \%$ & $-5.38 \%$ & $43.71 \%$ & $-3.47 \%$ \\
\hline Observation 12 & $-4.91 \%$ & $-4.58 \%$ & $23.99 \%$ & $-5.29 \%$ \\
\hline Observation 13 & $-6.37 \%$ & $-2.66 \%$ & $44.42 \%$ & $-5.33 \%$ \\
\hline Observation 14 & $-2.42 \%$ & $4.54 \%$ & $39.90 \%$ & $-0.79 \%$ \\
\hline Observation 15 & $-3.45 \%$ & $-1.49 \%$ & $14.05 \%$ & $-1.10 \%$ \\
\hline Observation 16 & $-4.33 \%$ & $0.81 \%$ & $14.27 \%$ & $-7.72 \%$ \\
\hline Observation 17 & $-4.96 \%$ & $1.66 \%$ & $88.72 \%$ & $30.30 \%$ \\
\hline Observation 18 & $-4.05 \%$ & $4.48 \%$ & $98.78 \%$ & $13.13 \%$ \\
\hline Observation 19 & $-6.06 \%$ & $-6.20 \%$ & $49.11 \%$ & $-2.55 \%$ \\
\hline Observation 20 & $-3.06 \%$ & $5.15 \%$ & $26.26 \%$ & $13.45 \%$ \\
\hline Observation 21 & $-5.05 \%$ & $-3.31 \%$ & $31.81 \%$ & $13.70 \%$ \\
\hline Observation 22 & $-7.65 \%$ & $5.38 \%$ & $28.01 \%$ & $1.01 \%$ \\
\hline CAAR & $-5.19 \%$ & $1.30 \%$ & $42.12 \%$ & $4.28 \%$ \\
\hline
\end{tabular}

Secondary Data, 2019

Table 2

Average Cumulative Abnormal Return of Portfolio Loser and Winner Compass 100 Index Formation Period and 6-Month Testing Period 2008 - 2018

\begin{tabular}{lllll}
\hline & \multicolumn{2}{c}{ Loser } & \multicolumn{2}{c}{ Winner } \\
\cline { 2 - 5 } & Period & Testing & Period & Testing \\
\hline Observation 1 & $-7.52 \%$ & $-1.64 \%$ & $80.51 \%$ & $-4.33 \%$ \\
Observation 2 & $-17.64 \%$ & $-0.79 \%$ & $241.60 \%$ & $-11.24 \%$ \\
Observation 3 & $-8.09 \%$ & $7.99 \%$ & $51.89 \%$ & $5.90 \%$ \\
Observation 4 & $-12.43 \%$ & $6.86 \%$ & $83.02 \%$ & $-0.72 \%$ \\
Observation 5 & $-6.51 \%$ & $-2.25 \%$ & $40.27 \%$ & $2.72 \%$ \\
\hline
\end{tabular}

Pratama, I. G. W., \& Rahyuda, H. (2019). Performance of stock portfolio based on contrarian strategy in indonesia stock exchange. International Research Journal of Management, IT and Social Sciences, 6(6), 220-228. 


\begin{tabular}{lllll}
\hline Observation 6 & $-7.97 \%$ & $-3.33 \%$ & $47.09 \%$ & $-4.59 \%$ \\
Observation 7 & $-8.95 \%$ & $8.16 \%$ & $42.77 \%$ & $26.53 \%$ \\
Observation 8 & $-6.81 \%$ & $-8.02 \%$ & $17.94 \%$ & $-2.01 \%$ \\
Observation 9 & $-8.22 \%$ & $-1.21 \%$ & $173.09 \%$ & $37.54 \%$ \\
Observation 10 & $-9.54 \%$ & $-11.21 \%$ & $46.08 \%$ & $41.84 \%$ \\
Observation 11 & $-7.37 \%$ & $8.28 \%$ & $58.99 \%$ & $-4.22 \%$ \\
CAAR & $-9.19 \%$ & $0.26 \%$ & $80.29 \%$ & $7.95 \%$ \\
\hline
\end{tabular}

Secondary Data, 2019

Table 3

Average Cumulative Abnormal Return of Portfolio Loser and Winner Compass 100 Index Formation and Testing Period 12 Months 2008 - 2018

\begin{tabular}{lllll}
\hline & \multicolumn{2}{c}{ Loser } & \multicolumn{2}{c}{ Winner } \\
\cline { 2 - 5 } & Formation & Testing & Formation & Testing \\
\hline Observation 1 & $-9.02 \%$ & $58.39 \%$ & $48.21 \%$ & $1.17 \%$ \\
Observation 2 & $-7.74 \%$ & $5.46 \%$ & $108.39 \%$ & $10.04 \%$ \\
Observation 3 & $-13.74 \%$ & $-4.61 \%$ & $70.50 \%$ & $5.26 \%$ \\
Observation 4 & $-12.96 \%$ & $-7.73 \%$ & $113.74 \%$ & $-22.62 \%$ \\
Observation 5 & $-9.82 \%$ & $28.34 \%$ & $372.86 \%$ & $55.40 \%$ \\
CAAR & $-10.66 \%$ & $15.97 \%$ & $142.74 \%$ & $5.38 \%$ \\
\hline
\end{tabular}

Secondary Data, 2019

To find out whether there is a difference in abnormal return between the formation period and the statistical test period, a different average or independent t-test was used on the loser and winner stock portfolio. By doing a different test, it can be seen the level of significance of the difference between the portfolio of the formation period of the test as shown in Table 4.

Table 4

Average Difference Test Results for Abnormal Return of Portfolio Loser and Winner Compass 100 Index Formation Period and Testing Period 2008 - 2018

\begin{tabular}{|c|c|c|c|c|c|}
\hline \multirow{3}{*}{ No } & \multirow{3}{*}{ Period } & \multicolumn{4}{|c|}{ Portfolio } \\
\hline & & \multicolumn{2}{|c|}{ Loser } & \multicolumn{2}{|c|}{ Winner } \\
\hline & & Difference & Sig & Difference & Sig \\
\hline 1 & 3 months & $-6.49 \%$ & 0.000 & $37.85 \%$ & 0.000 \\
\hline 2 & 6 months & $-9.44 \%$ & 0.000 & $72.35 \%$ & 0.003 \\
\hline 3 & 12 months & $-26.63 \%$ & 0.064 & $137.36 \%$ & 0.053 \\
\hline
\end{tabular}

Secondary Data, 2019

Table 5

Average Difference Test Results of Winner Portfolio Stocks with Compass 100 Index Loser Stock Portfolios Testing Period $2008-2018$

\begin{tabular}{llll}
\hline No & Period & Difference & Sig \\
\hline 1 & 3 months & $-2.98 \%$ & 0.295 \\
2 & 6 months & $-7.69 \%$ & 0.209 \\
3 & 12 months & $10.59 \%$ & 0.589 \\
\hline
\end{tabular}

Secondary Data, 2019

\subsection{Hypothesis testing}

Hypothesis testing is carried out from the results obtained in the average two different tests as in Table 4 and Table 5 , to find out whether the first, second, and third hypotheses made previously can be accepted or rejected. 
First Hypothesis

Based on Table 4, the first hypothesis can be accepted in periods of 3 months and 6 months. The first hypothesis in that period is acceptable because the difference in the average is positive at $37.85 \%$ and $72.35 \%$ and the significance level is below 0.05 . These results mean that there is a positive and significant difference in abnormal return between a portfolio of shares in the formation period and the portfolio of the test period based on high abnormal return (winner). In the 12-month period, the significance level is $0.053(>0.05)$ which means that there is a positive and insignificant difference between the abnormal return of the formation period and the testing period on the winner's stock portfolio.

\section{Second Hypothesis}

From Table 4, the second hypothesis can be accepted in periods of 3 months and 6 months. The first hypothesis in that period was acceptable because the difference was negative of $-6.49 \%$ and $-9.44 \%$ and the significance level was below 0.05 . These results mean that there are negative and significant differences in abnormal return between the formation period stock portfolio and the testing period stock portfolio based on low abnormal return (loser). In the 12-month period, the significance level is $0.064(>0.05)$ which means that there is a negative and insignificant difference between the abnormal return of the formation period and the testing period of the loser stock portfolio within a period of 12 months.

\section{Third Hypothesis}

From Table 5, the third hypothesis cannot be accepted in the 3 months and 6 month periods. The third hypothesis in the period was rejected because the difference was negative by $-2.98 \%$ and $-7.69 \%$ and the significance level was above 0.05 . These results mean that the performance of the winner stock portfolio is greater than the loser stock portfolio with insignificant differences. In period 12, the third hypothesis is also unacceptable because even if a negative difference is obtained, the level of difference is not significant. These results mean that the loser stock portfolio produces greater and insignificant performance compared to the winner stock portfolio in a period of 12 months.

\subsection{The difference in performance between the stock portfolio formation period with the stock portfolio testing period based on high abnormal returns.}

This study found that in the period 2008 to 2018, portfolios formed from stocks listed on the Kompas 100 index on the Indonesia Stock Exchange with high abnormal returns in the formation period had positive and significant differences in the testing period. The difference is seen in the declining performance of winner shares (return) significantly in the next period (testing) in a period of 3 and 6 months. This is because investors overreact to these shares by buying highlevel stock returns without regard to fundamental values and macro conditions in general. Such an excessive reaction is the beginning of a reversal event. The reversal effect is shown by the drastic decline in the performance of the winner stocks close to the value received by the market. The decline was caused by investors who reduced the number of shares purchased and began to sell slowly. However, the overreaction of the winner's stock portfolio on average has not yet caused a reversal in price, because during the testing period the performance remained positive. Despite the decline, the winner stock portfolio in the period of 3 and 6 months still produces positive abnormal returns and there is no reversal of the direction of abnormal return from initially positive to negative.

Slightly different results were obtained in the 12 month testing period, there were positive but not significant differences. There is a decrease in the performance of the stock portfolio (return), but on average there is no reversal of the direction of being negative from what originally had a positive return. At the end of the period, the winner's stock portfolio continues to produce a positive return. This does not support the existence of an overreaction hypothesis which causes a drastic price reduction and reversal becomes negative. This is due to the shares in the winner's portfolio consisting of shares of the Kompas 100 index which have fundamental aspects and good liquidity. Psychologically investors still believe that the winner shares still have good performance.

Pratama, I. G. W., \& Rahyuda, H. (2019). Performance of stock portfolio based on contrarian strategy in indonesia stock exchange. International Research Journal of Management, IT and Social Sciences, 6(6), 220-228. 
3.4 The difference in performance between the stock portfolio formation period with the stock portfolio testing period based on low abnormal returns.

The low abnormal return portfolio (loser) of the Kompas 100 index in the formation period has a negative and significant difference to the testing period in 3 and 6 months. The difference in abnormal return performance is shown by the significant increase in returns or performance of loser stocks in the next period (testing) in a period of 3 and 6 months. This is caused by overreaction (overreaction) by investors. Overreaction is initiated by investors selling their shares that have just declined without regard to the fundamental value of the stock price. In the next period, investors buy shares spontaneously when they realize they have overreacted. These events cause stocks with low abnormal returns to reverse be higher close to the value received by the market.

Slightly different results were obtained in the 12 month testing period, that there were negative but not significant differences at the 5\% level between the formation period and the testing period. There was a reversal in the direction of prices from initially negative to positive at the end of the period, but on average the level of difference was not significant. This supports the overreaction hypothesis which causes price increases and reversals to be positive. This is due to the stocks in the loser portfolio consisting of Kompas 100 index shares which have good fundamental performance and liquidity. Still, investors believe that the price decline is only temporary, so that loser stocks in the long run still have good performance.

\subsection{The difference in performance between high abnormal return stock portfolios and low abnormal return stock portfolios in the test period}

Based on the results of the study in Table 5, the low abnormal return portfolio (loser) has a negative and insignificant difference to the high abnormal return stock portfolio (winner) in the test period within a period of 3 and 6 months. The performance of the winner stock portfolio which is greater than the loser stock portfolio is caused by the overreaction that does not cause a reversal of the price from what should be positive to negative. But what happened was that the winner's stock portfolio continued to produce a positive performance at the end of the period of 3 and 6 months.

Different results were obtained over a 12-month period, indicating the loser stock portfolio had positive and insignificant differences. This happens because the event of overreaction within a period of 12 months causes a reversal of the price direction from the original negative (loser) to positive (winner). At the end of the formation period, investors began to realize that they had overreacted to the development of information by buying shares at a price that was too high (winner) and ignoring the performance of shares that have declined (loser). This overreaction results in an upward movement in the price of loser shares and a sharp fall in winner shares. At the end of the test period, stocks with low abnormal returns will be reversed (reversal) to be higher in a period of 12 months. These events provide an opportunity for contrarian investors to choose stocks that are too cheap.

\subsection{Implementation of contrarian strategies on the Kompas 100 stock portfolio}

Contrarian strategies can be applied if loser stocks experience a reversal to winner shares in the next period. Loser stock portfolio performance must also be greater than the performance of winner shares in the next period. The results of the research shown in Table 5, the performance of loser stock portfolios outperformed the winner stock portfolio in a period of 12 months. Based on these results, the contrarian strategy can only be applied within a period of 12 months on loser and winner shares. Contrarian investment strategies in winner shares are carried out by selling stocks that have positive abnormal returns and buying stocks that have low abnormal returns in the formation period. Shares that initially have a good performance or a positive rate of return (winner) will experience a decline in performance in subsequent periods. Vice versa, stocks that initially had poor performance or negative returns (losers) will experience an increase in performance but in subsequent periods

The decline and increase in the performance of stocks and events that occur both from internal and external causes investors to overreact. After overreacting, the investor will react later. This is indicated by changes in prices and performance or stock returns. Stock returns are the opposite of the phenomenon of overreaction. Shares that are usually bought by investors because they have high returns are less desirable, while stocks that are low-value and are less desirable begin to be bought by investors. Previously lower stock returns (losers) are higher.

The reversal of the average low abnormal return at the end of the testing period implies that the contrarian strategy within 12 months can be applied to Kompas 100 index shares in the Indonesian capital market during the study period. 
Based on the results of the study also found that the momentum strategy can be applied to Kompas 100 index stocks in a period of 3 and 6 months because on average it produces a negative difference. The negative difference means that the winner's portfolio performance is superior to the loser's stock portfolio. Despite a decline in performance, on average it still produces a positive abnormal return at the end of the period. The momentum investment strategy is a strategy of buying winner shares that should produce a positive abnormal return and a loser stock portfolio producing a negative abnormal return at the end of the testing period.

This finding supports the results of the Lerskullawat \& Ungphakorn (2018), a study that concluded that the contrarian strategy can be applied by overreaction in the Thai capital market so that it causes a reversal of the performance of the stock portfolio at the end of the period. Some research results support the existence of contrarian in the capital market that has been developed, as conducted by Bhoolkesorn (2008), in the US capital market, and Wu (2011), in the Chinese capital market found that consistent overreaction occurs so that contrarian strategies can be applied.

\section{Conclusion}

Based on the testing that has been done, the conclusion that can be drawn from this study is the contrarian strategy can be applied within a period of 12 months. The performance of the winner's stock portfolio is slightly superior compared to the performance of the loser stock portfolio in that period. In the 12-month period, there are positive differences, which means that the loser stock portfolio produces greater performance than the winner stock portfolio at the end of the testing period.

\section{Suggestion}

1) In the development of knowledge about financial behavior related to psychological factors can influence stock transaction decisions, so that the benefits of capital market players can be felt in a combination of other sciences such as macroeconomic theory and microeconomics.

2) Investors are advised to use a contrarian strategy in trading shares, especially on Kompas 100 index shares with a 12-month period. The momentum strategy can also be used within 3 and 6 months. International diversification is also an important in-stock selection investment. International diversification will provide greater benefits for investors compared to only investing in the domestic market.

Further research is suggested to use or add another approach. Other technical approaches can use transaction volume, average adjusted models (mean adjusted models), and market models (market models). In addition to technical analysis, there are also fundamental stock analyzes, including the price to earnings ratio, price to book value approach, price to sales ratio and, price to cash flow ratio. Further research is also suggested to develop by diversifying into other indices such as LQ45, BUSINESS-27, PEFINDO25, SRI-KEHATI, IDX30, Sharia Index, and MNC36 Index.

\section{Conflict of interest statement}

The authors declared that they have no competing interests.

\section{Statement of authorship}

The authors have a responsibility for the conception and design of the study. The authors have approved the final article.

\section{Acknowledgments}

The authors would like to thank the reviewer for their consideration of the further process of the present paper. Thanks to the editor of IRJMIS for the valuable support, time as well as advice.

Pratama, I. G. W., \& Rahyuda, H. (2019). Performance of stock portfolio based on contrarian strategy in indonesia stock exchange. International Research Journal of Management, IT and Social Sciences, 6(6), 220-228. 


\section{References}

Alper, D., \& Aydogan, E. (2017). The Profitability of Contrarian Strategy: Borsa Istanbul Case. Muhasebe ve Finansman Dergisi, (74).

Bhoolkesorn, K. (2008). Decomposition of trading abnormal return: case study of contrarian and momentum strategies (Doctoral dissertation, Faculty of Commerce and Accountancy Thammasat University).

Block, S. B., \& Hirt, G. A. (1989). Foundations of financial management. Homewood. IL: Irwin.

Bodie, Z. K., \& Marcus, A. AJ (2010). Essentials of investments.

De Bondt, W. F., \& Thaler, R. (1985). Does the stock market overreact?. The Journal of finance, 40(3), 793-805. https://doi.org/10.1111/j.1540-6261.1985.tb05004.x

Farag, H. (2015). Long-term Overreaction, Regulatory Policies and Stock Market Anomalies: Evidence from Egypt. Journal of Emerging Market Finance, 14(2), 112-139. https://doi.org/10.1177\%2F0972652715584265

French, S., \& Insua, D. R. (1989). Partial information and sensitivity analysis in multi-objective decision making. In Improving Decision Making in Organisations (pp. 424-433). Springer, Berlin, Heidelberg. https://doi.org/10.1007/978-3-642-49298-3_39

Khatua, S., \& Pradhan, H. K. (2014). Indication of Overreaction with or without Stock Specific Public Announcements in Indian Stock market. Vikalpa, 39(3), 35-50. https://doi.org/10.1177\%2F0256090920140303

Lerskullawat, P., \& Ungphakorn, T. (2018). Does overreaction still exist in Thailand?. Kasetsart Journal of Social Sciences. https://doi.org/10.1016/j.kjss.2018.02.001

Moskowitz, T. J., \& Grinblatt, M. (1999). Do industries explain momentum?. The Journal of finance, 54(4), 12491290. https://doi.org/10.1111/0022-1082.00146

Piccoli, P., Chaudhury, M., Souza, A., \& da Silva, W. V. (2017). Stock overreaction to extreme market events. The North American Journal of Economics and Finance, 41, 97-111. https://doi.org/10.1016/j.najef.2017.04.002

Pramanaswari, A. S. I., \& Yasa, G. W. (2018). Graham \& Dodd theory in stock portfolio performance in LQ 45 index at Indonesia stock exchange. International Research Journal of Management, IT and Social Sciences, 5(6), 52-59. https://doi.org/10.21744/irjmis.v5n6.338

Sharpe, W., Alexander, G., \& Bailey, J. W. (1990). In vestments.

Wartawan, P. G. (2017). The effectiveness of the use of portfolio assessment by controlling prior knowledge to enhance scientific attitude among senior high school students. International Journal of Physical Sciences and Engineering, 1(3), 9-18. https://doi.org/10.21744/ijpse.v1i3.54

Wiagustini, N. L. P. (2008). Profitabilitas strategi investasi kontrarian di Bursa Efek Indonesia. Jurnal Manajemen dan Kewirausahaan, 10(2), 105-114. https://doi.org/10.9744/jmk.10.2.pp.\%20105-114

Widiastuti, E. (2013, November). Short contrarian investment strategy: Pengujian winner-loser anomaly pada SahamSaham di Bursa Efek Indonesia. In Performance (Vol. 14, No. 2).

$\mathrm{Wu}, \mathrm{Y}$. (2011). Momentum trading, mean reversal and overreaction in Chinese stock market. Review of Quantitative Finance and Accounting, 37(3), 301-323. https://doi.org/10.1007/s11156-010-0206-z 